\title{
Separation of Anti-Ia (I-Region Associated Antigens) from Anti-H-2 Antibodies in Complex Sera, by Absorption on Blood Platelets. Description of Three New Ia Specificities 1
}

\author{
Jacques Colombani ${ }^{2}$, Monique Colombani ${ }^{2}$, Donald C. Shreffler ${ }^{3}$ \\ and Chella David ${ }^{3}$ \\ Department of Human Genetics, University of Michigan Medical School, \\ Ann Arbor, Michigan, U.S.A.
}

\begin{abstract}
$\mathrm{H}-2$ antigens are expressed in substantial amounts on murine blood platelets (for $\mathrm{H}-2$ antigenic content 1 lymphocyte $\sim 50$ platelets) whereas Ia antigens are probably not expressed at all (minimal Ia antigenic content more than 35 times lower than for $\mathrm{H}-2$ ). This property of blood platelets makes them very useful for the selective absorption of anti- $\mathrm{H}-2$ antibodies from complex sera and for the preparation of specific anti-Ia antibodies from such sera. In 20 sera produced against the complete $\mathrm{H}-2$ complex, 12 sera contained anti-Ia antibodies beside the expected anti-H-2 antibodies. In two sera, separation of the anti-Ia antibodies was easily obtained by absorption of the anti-H-2 antibodies on platelets. The analysis of one serum (C3H.Q $\times$ B10.D2) anti-C $3 \mathrm{H}[(\mathrm{q} \times \mathrm{d})$ anti-k] showed that, in addition to the expected anti-H-2.23 and anti-Ia.2 antibodies, it contained at least three other Ia antibodies, separable by absorption on lymphocytes, which recognized three antigens-Ia. I7, determined by the haplotypes $k, f, s, r, j$; Ia. 18, determined by the haplotypes $k, f, s$; and Ia. 19 determined by the haplotypes $k$ and $r$. The genes are located in the $I-A$ and/or $I-B$ subregions of the $H-2$ complex.
\end{abstract}

Received for publication 30 June, accepted 14 August 1975

Ia (I-region associated) antigens are a new class of alloantigens on the membranes of murine cells (David et al. 1973, Hauptfeld et al. 1973, Sachs \& Cone 1973, Hammerling et al. 1974). They are determined by genes located in the $H-2$ complex at the $I$ region, which was initially defined by immune response (Ir) genes (Benacerraf \& McDevitt 1972). The $I$ region is divided into at least three subregions and the $H-2$ complex can

\footnotetext{
This work was supported by U.S.P.H.S. Program Project Grant GM 15419 and U.S.P.H.S. Research Grant AI 11962. D.C.S. is recipient of U.S.P.H.S. Research Career Development Award HL 24980. J. C. was supported by the French Ministère de l'Education Nationale. 2Permanent address: Unité de Recherche sur l'Immunogénétique de l'Histocompatibilité Humaine, U93 INSERM, Hôpital Saint-Louis, 75475 Paris Cedex 10, France.

${ }^{3}$ Present address: Department of Genetics, Washington University School of Medicine, St. Louis, Mo 63110, U.S.A.
} 
be considered as being composed of six regions or sub-regions, $K, I-A, I-B, I-C, S$, $D^{*}$ (for review, see Shreffler \& David 1975, Sachs et al. 1975). Originally anti I-a sera were induced through immunisation between strains carrying recombinant haplotypes such that donor and recipient shared in common all the genes of the $\mathbf{H - 2}$ complex except those of the $I$ region (David et al. 1973, Hauptfeld et al. 1973). It is now apparent that many immune sera induced against the products of the whole $H-2$ haplotype contain both anti-H-2 ( $\mathrm{K}$ and/or $\mathrm{D}$ ) and anti-Ia antibodies (Shreffler \& David 1975, Sachs \& Cone 1975). When strains carrying the appropriate recombinant haplotypes are available, their lymphocytes can be used for selective absorption of anti-H-2 antibodies. On the other hand, the different tissue distribution of $\mathrm{H}-2$ and Ia antigens should also permit the absorption of anti$\mathrm{H}-2$ antibodies. Contrary to $\mathrm{H}-2$ antigens which are expressed on almost all tissues (Snell \& Stimpfling 1964), Ia antigens are detected only on certain cells-essentially B lymphocytes, macrophages, epidermal cells and sperm cells (Shreffler \& David 1975, McDevitt et al. 1974, Hauptfeld et al. 1974, Unanue et al. 1974). They are also expressed on thymocytes but probably more weakly and/or only on a subpopulation of these cells (Shreffler \& David 1975, Fre-

\footnotetext{
*The "haplotype composition" of a given strain when mentioned in this report refers to the genes of the $H-2$ complex at the six regions or subregions listed in the order, $K, I-A, I-B, I-C, S, D$. The nomenclature for the $H-2$ complex and the Ia antigens will be as recently proposed (Klein et al. 1974, Shreffler et al. 1974). Whenever possible without ambiguity the $\mathrm{H}-2$ haplotype will be designated by the italicized superscript symbol printed on line with the text (e.g. $k$ for $H-2^{k}$ ).

Abbreviations used in this paper: LCT: dye exclusion lymphocytotoxicity technique; LyCF: spleen lymphocyte complement fixation technique; PICF: platelet complement fixation technique.
}

linger et al. 1974a). Ia antigens are not detected on erythrocytes, or on kidney, liver and brain tissues (Shreffler \& David 1975, McDevitt et al. 1974). Erythrocytes and $T$ cell tumors have already been used for the selective absorption of anti-H-2 antibodies (Davies \& Hess 1974, Sachs \& Cone 1975). It will be shown in this report that blood platelets can be very effective for this absorption.

We have aiready shown (Colombani et al. 1975) by a direct platelet complement fixation test $(\mathrm{P} 1 \mathrm{CF})$ and by absorption-elution analyses that platelets carry a substantial number of $\mathrm{H}-2$ antigens without detectable Ia antigens. For that reason sera reacting with the lymphocytes, but not with the platelets, of a given strain are very likely to contain anti-Ia antibodies. Such a study has been done on 20 immune sera, 12 of which were shown to contain well-defined anti-Ia antibodies in addition to anti-H-2 antibodies. A detailed study of one of these sera showed that the separation of anti-H-2 and anti-Ia antibodies can be easily obtained. Another serum developed against the products of the $H-2^{k}$ haplotype defined three new Ia specificities which will be described.

\section{Materials and Methods}

Animals and reagents: Inbred mouse strains and $F_{1}$ hybrids used in this study were all derived from the colony maintained in the Department of Human Genetics, University of Michigan. Immune sera were produced as previously described (Shreffler et al. 1966).

Preparation of cells: Spleen lymphocytes used for absorption or lymphocyte complement fixation ( $\mathrm{LyCF}$ ) were purified by flotation on Ficoll-Sodium metrizoate solution (Thorsby \& Bratlie 1970), then washed and suspended in saline containing $0.1 \% \mathrm{NaN}_{3}$ and $0.1 \%$ bovine serum albumin, at the concentration 
of 20,000 cells $/ \mu$ l. Lymph node lymphocytes were prepared without flotation. The lymphocytes used for absorption were a mixture of lymph node and spleen lymphocytes approximately in equal numbers. They were used less than $24 \mathrm{~h}$ after preparation.

Blood platelets were obtained by differential centrifugation from peripheral blood. The bleeding was made from the retroorbital sinus and the blood immediately mixed in a plastic tube with saline containing $5 \% \mathrm{Na}_{2}$ EDTA in the proportion of $4 \mathrm{vol}$ of blood for 1 vol of anticoagulant solution. The platelets were then sedimented by centrifugation $\left(1,600 \mathrm{~g} / 20 \mathrm{~min} / 4^{\circ} \mathrm{C}\right)$ and washed three times in saline. They were finally suspended in saline containing $0.1 \% \mathrm{NaN}_{3}$ at the concentration of $4 \times 10^{6} / \mu \mathrm{l}$ and kept at $+4^{\circ} \mathrm{C}$ until used. They could be kept up to one month without any appreciable change in antigenic activity. The yield of platelet preparations was $0.95 \pm 0.15 \times 10^{9} \mathrm{per} \mathrm{ml}$ of blood for 53 preparations made in 18 different strains. The suspensions contained less than 1 leucocyte $/ 1,000$ platelets. The same platelet suspensions were used for absorption and PICF.

Serological tests: Dye exclusion LCT (David et al. 1973, Frelinger et al. 1974a), LyCF and P1CF (Colombani et al. 1975) microtechniques were performed as previously described. In all cases unabsorbed rabbit serum was used as the source of complement.

Absorption-elution: Absorptions were made by incubation for $30 \mathrm{~min}$ or $1 \mathrm{~h}$ at $37^{\circ} \mathrm{C}$ of an appropriate dilution of immune serum with an appropriate number of platelets or lymphocytes. After sensitization the cells were washed and elution performed in a small volume of saline acidified $(\mathrm{pH} 3.0)$ with $\mathrm{HCl}$ $0.1 \mathrm{~N}$. After $20 \mathrm{~min}$ at room temperature the suspension was centrifuged and the supernatant decanted and neutralized ( $\mathrm{pH} 7.0$ ) with $\mathrm{NaOH} 0.04 \mathrm{~N}$ (Schulman et al. 1964).
Results

Screening for sera containing anti-Ia antibodies; Twenty immune sera were produced by immunization against strains carrying the $H-2$ haplotypes $b, d, f, k, p, q, r, s$ (nos. $1-20$ in Table 1). In 15 cases the donor-recipient combination allowed immunization against products of the whole $H-2$ complex. In four cases immunization against the products of the $H-2 D$ region was "blocked" by the presence of an allele shared in common by donor and recipient. In one case (serum no. 6 ), immunization against the products of the $H-2 K, I-A$ and $I-B$ regions was similarly blocked.

The reactivity of the sera was studied against a panel of 15 strains carrying nine independent $H-2$ haplotypes $(b, d, f, j, k, p, q$, $r, s)$ and six recombinant haplotypes $(t l, y l$, $h 4, a, i 5, t 4$ ) (see list of the strains in Table 2), by the LCT, LyCF and PICF techniques. Essentially two patterns of reactivity were observed-the $\mathrm{H}-2$ pattern, LCT(+) with $100 \%$ of lymphocyte killing, LyCF $(+)$, PlCF(+)—and the Ia-pattern, LCT(+) with a maximum lymphocyte killing less than $75 \%$, LyCF $(+), \operatorname{PICF}(-)$. The $\mathrm{H}-2$ pattern was observed against the immunizing strain, or the strains carrying at the $H-2 K$ and/or $D$ regions the same genes as the immunizing strain. The Ia pattern was observed in strains with recombinant haplotypes when the target strain shared part of all of the $I$ region with the immunizing strain. In addition, a number of cross-reactions of both anti-H-2 and anti-Ia antibodies were observed, as expected from the H-2 (Démant 1973) and Ia (Shreffler \& David 1975, Sachs et al. 1975) charts.

All sera contained the anti-H-2K and/or D antibodies expected from the immunization combination (Table 1). Two sera contained only anti-H-2 antibodies (nos. 5 and 6). Twelve sera contained, in addition, well characterized anti-la antibodies-Ia.2 (no. 7), Ia.1, 2, 3 (nos. 8 and 9), Ia.8 (no. 3). Ia. 9 
Table 1

List of immune sera

\begin{tabular}{|c|c|c|c|c|c|}
\hline \multirow{2}{*}{$\#$} & \multirow{2}{*}{ Recipient } & \multirow{2}{*}{ Donor } & \multirow{2}{*}{$\begin{array}{c}\text { Haplotype } \\
\text { combination }\end{array}$} & \multicolumn{2}{|c|}{$\begin{array}{c}\text { Principal } \\
\text { specificities }\end{array}$} \\
\hline & & & & Anti-H-2 & Anti-Ia \\
\hline 1 & $(\mathrm{C} 3 \mathrm{H} \times \mathrm{D} 2)$ & C3H.B 10 & $(k \times d)$ anti-b & 33,2 & 9 \\
\hline 2 & $\mathrm{C} 3 \mathrm{H}$ & C3H.B 10 & $k$ anti-b & $33,2,6$ & $?$ \\
\hline 3 & $(\mathrm{HTH} \times \mathrm{C} 3 \mathrm{H} . \mathrm{Q})$ & C3H.B10 & $(h \times q)$ anti-b & 33 & 8 \\
\hline 4 & (B10 $\times$ A.CA & B10.D2 & $(b \times f)$ anti-d & $4,31,3, \ldots$ & $?$ \\
\hline 5 & (A.BY $\times$ B10.S) & A.CA & $(b \times s)$ anti-f & $9,37,8$ & \\
\hline 6 & $(\mathrm{~B} 10 \times \mathrm{A})$ & B 10.BR & (b $\times$ a) anti-k & 32 & \\
\hline 7 & (C3H.Q $\times$ B10.D2) & $\mathrm{C} 3 \mathrm{H}$ & $(\mathrm{q} \times \mathrm{d})$ anti-k & 23 & $2 *$ \\
\hline 8 & $\mathrm{C} 3 \mathrm{H} . \mathrm{OH}$ & $\mathrm{C} 3 \mathrm{H}$ & $\mathrm{o}_{2}$ anti-k & $11,23,3, \ldots$ & $, 1,2,3$ \\
\hline 9 & C3H.OL & $\mathrm{C} 3 \mathrm{H}$ & $o_{1}$ anti-k & $11,23,3$ & $1,2,3$ \\
\hline 10 & (C 3 H.B $10 \times$ B $10 . A)$ & B10.P & $(b \times a)$ anti-p & 16,7 & $?$ \\
\hline 11 & $(\mathrm{~B} 6 \times \mathrm{A})$ & Blo.P & $(b \times a)$ anti-p & $16,37,7$ & 13 \\
\hline 12 & $(\mathrm{~A} \times \mathrm{B} 10 . \mathrm{S})$ & B10.P & $(\mathrm{a} \times \mathrm{s})$ anti-p & 16 & 13 \\
\hline 13 & $(\mathrm{C} 3 \mathrm{H} \times \mathrm{B} 10)$ & C.3H.Q & $(\mathrm{k} \times \mathrm{b})$ anti-q & 17,13 & 13 \\
\hline 14 & (AKR.M $\times$ C 3 H.BlO) & C $3 H . \tilde{Q}$ & $(m \times b)$ anti-q & 17 & 13 \\
\hline 15 & $(\mathrm{D} 1 \times \mathrm{D} 2)$ & CR & $(q \times d)$ anti-r & $18,1, \ldots$ & 12 \\
\hline 16 & $($ B $10 \times$ A.CA $)$ & A.SW & $(b \times f)$ anti-s & 19,3 & $?$ \\
\hline 17 & $(B 10 \times A . C A)$ & $B 10.5$ & $(b \times f)$ anti-s & 19,3 & $?$ \\
\hline 18 & $(\mathrm{~B} 10 \times \mathrm{A})$ & A.SW & $(\mathrm{b} \times \mathrm{a})$ anti-s & 19 & 12 \\
\hline 19 & $(\mathrm{~B} 10 \times \mathrm{A})$ & B $10 . S$ & $(b \times a)$ anti-s & 19 & 12 \\
\hline 20 & (C.3H.RHI x B10.K) & B10.S & $(\mathrm{r} \times \mathrm{k})$ anti-s & 19,36 & $?$ \\
\hline 21 & (C3H.Q $\times$ B10.D2) & AQR & $(\mathrm{q} \times \mathrm{d})$ anti-yl & - & $2 *$ \\
\hline
\end{tabular}

* indicates the presence of additional Ia specificities.

(no.1), la.12 (nos. 15, 18 and 19), Ia.13 (nos. 11, 12, 13 and 14). In certain cases (sera nos. 7,8 and 9 for instance) extra reactions with an Ia pattern were observed. Six sera (nos. 2, 4, 10, 16, 17 and 20) contained, apart from the expected anti-H-2 antibodies, weak cytotoxic antibodies (low titre and low percentage of killing) not yet identified. Out of the 20 sera screened, three were selected for further study:-no. 6 $(b \times a)$ anti-k, (anti-H-2.32) as an example of immune serum containing only anti-H-2 antibodies; no. $14(m \times b)$ anti- $q$, (anti$\mathrm{H}-2.17$ + Ia.13) as an example of anti-H-2 la serum; and no. $7(q \times d)$ anti-k (anti$\mathrm{H}-2.23$ + Ia.2, . .) for the study of the new anti-Ia antibodies it contained. Another serum not among the 20 sera was also used, no. $21(q \times d)$ anti-yl similar to no. 7 but for the absence of anti-H-2 antibodies, the $H-2 K$ and $D$ regions being blocked by the immunization combination.

Quantitative absorption of anti-H-2 and anti-Ia antibodies with lymphocytes and platelets: This experiment was carried out in order to evaluate the number of cells needed to absorb each type of antibody from two immune sera with about the same titre (Fig. 1). A parallel absorption of the anti-H-2.32 serum was observed with lymphocytes and platelets. A significant decrease in titre was induced by $1-2 \times 10^{6}$ lymphocytes and 1-2 $x$ $10^{8}$ platelets. A complete absorption was obtained with $16 \times 10^{6}$ lymphocytes, and almost complete with $16 \times 10^{8}$ platelets. In this particular experiment the $\mathrm{H}-2$ antigenic content of one lymphocyte was thus about 
the same as that of 100 platelets. The specificity of the absorption was shown by the fact that no decrease of titre was induced by incubation with large numbers $\left(64 \times 10^{6}\right.$ lymphocytes or $40 \times 10^{8}$ platelets) of $\mathrm{H}-2.32$ negative cells (B10.A (4R)). B10.K lymphocytes absorbed both anti-H-2 and anti-Ia antibodies in about the same way. A significant absorption of the anti-Ia.2 antibody was obtained with $2 \times 10^{6}$ lymphocytes and an almost complete absorption with $16 \times 10^{6}$ lymphocytes. On the other hand, no decrease of titre was observed even with $70 x$ $10^{8}$ platelets. As $2 \times 10^{8}$ platelets absorbed an anti-H-2 antibody when $70 \times 10^{8}$ platelets failed to absorb an anti-Ia antibody, it was possible to conclude that the Ia antigenic content of platelets was more than 70:2= 35 times lower than their $\mathrm{H}-2$ antigenic content.
Separation of anti-H-2.17 from anti-Ia.13 in serum no. 14- $(m \times b)$ anti-q (Fig. 2): When tested against the panel this serum reacted with an $\mathrm{H}-2$ pattern against C3H.Q $\left(\mathrm{H}-2^{\mathrm{g}}\right)$ and with an Ia pattern against B 10.M ( $\left.\mathrm{H}-2^{f}\right)$ and B10.P $\left(H-2^{\mathrm{P}}\right)$. The last two strains are Ia.13(t). The serum thus contained both anti-H-2.17 and anti-Ia.13 antibodies. In addition, it reacted against $\mathrm{B} 10 . \mathrm{T}(6 \mathrm{R})$ $\left(H-2^{y^{2}}, \quad H-2.17(+) \quad\right.$ Ia.13(+)) and AQR $\left(H-2^{y !}, \mathrm{H}-2.17(+)\right.$ Ia.13(-)) with an $\mathrm{H}-2$ pattern. These two strains, together with B 10.M (H-2.17(-) Ia.13(+)), were used to dissociate the reactivities due to the two antibodies. Lymphocytes and platelets from the three strains were used for absorptionelution analyses. The reactivity of the unabsorbed serum (curve $a$ in Fig. 2) against $A Q R$ and $B 10 . M$ respectively showed that the anti-H-2.17 titre was much higher than

ANTI-10. f. $2(+H-2.23)(\mathrm{q} \times \mathrm{d})$ anti-k ANTI-H2.32 (bxa) anti-k
(B1O $\times$ A) ANTI-B10.BR-B1O.K TARGET

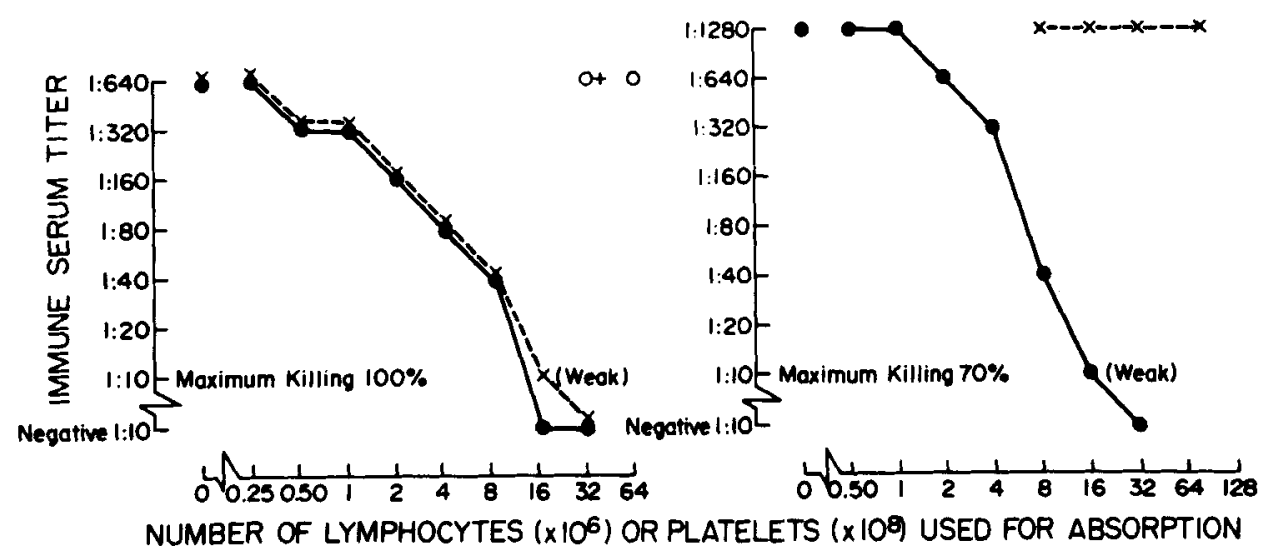

Figure 1. Quantitative absorption of anti-H-2 and anti-la antibodies with lymphocytes and blood platelets. $50 \mu h$ of immune serum diluted 1:10 was absorbed with the indicated numbers of Bl0.K lymphocytes $(\bullet), B 10 . K$ platelets $(\mathrm{X}), \mathrm{B} 10 . \mathrm{A}(4 \mathrm{R})$ lymphocytes $(O)$ or B $10 . \mathrm{A}(4 \mathrm{R})$ platelets $(t)$. After absorption the titer of the residual antibody was determined with the dye exclusion lymphocytotoxicity test. Each point represents the residual titer. On the left hand panel is shown reactivity of an anti-H-2 serum (\#6) $[(\mathrm{B} 10 \times \mathrm{A})$ anti-B 10.BR; ( $b \quad x$ a) anti-k] against B10.K target lymphocytes. On the right hand panel is shown reactivity of an Ia.2( $+\mathrm{H}-2.23)$ serum (\#7) [(C3H.Q $\times$ B10.D2) anti-C3H; ( $\times$ d) anti-k]. Since AQR target lymphocytes were used with this serum, only the anti-Ia antibodies reacted against the target. 
the anti-la. 13 titre. Absorption on (6R) lymphocytes (curve b) removed both anti-H-2 and anti-la antibodies. Eluate from $(6 \mathrm{R})$ lymphocytes (curve c) contained both activities. Absorption on (6R) platelets (curve d), AQR platelets (curve h) and lymphocytes (curve f) removed only anti-H-2 antibody, and the corresponding eluates (curves $\mathrm{e}, \mathrm{i}, \mathrm{g}$ ) contained only anti-H-2 antibody. B10.M lymphocytes absorbed (curve j) and released (curve $k$ ) anti-la antibody. B10.M platelets had no activity in absorption (curve l) or elution (curve $\mathrm{m}$ ). Apart from the LCT tests shown in Fig. 2, LyCF and P1CF tests were also done with all reagents. Perfectly consistent results were obtained. All reagents expected to contain only anti-H-2 antibodies $(e, g, i, j)$ reacted only with (6R) and AQR lymphocytes and platelets. Reagents expected to contain only

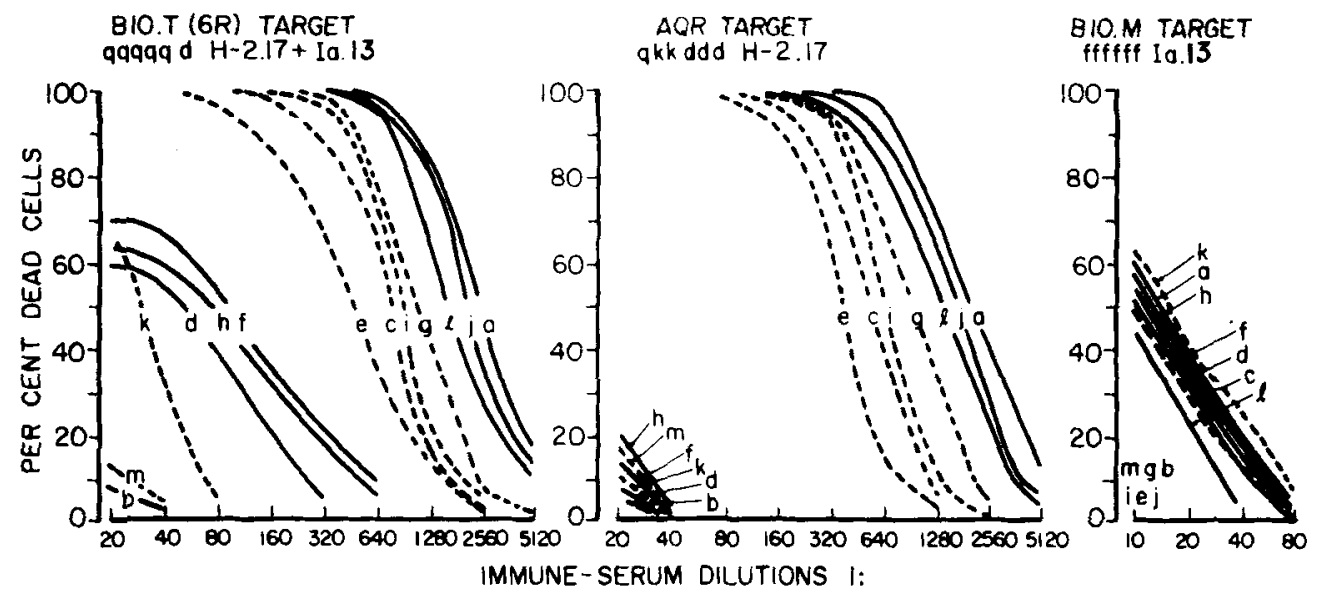

Figure 2. Absorption-elution on lymphocytes and platelets of an anti-H-2.17+ Ia.13 serum (\#14) [AKR.M $\times$ C3H.B10) anti-C3H.Q; $(m \times b)$ anti-q]. The curves represent the results of dye exclusion lymphocytotoxicity tests with serum \# 14 before or after absorption (solid lines) or with eluates (broken lines). Absorption of $250 \mu /$ of serum diluted $1: 10$ was done with $1 \times 10^{8}$ lymphocytes, or $8 \times 10^{9}$ platelets. For elution, these numbers of cells were further sensitized with $100 \mu \ell$ of undiluted serum. After washing the elution was made in a vol of $50 \mu \ell$. In addition to the unabsorbed serum (a) the reagents were as follows:

Cells used were from strains

\begin{tabular}{lcccc}
\multicolumn{1}{c}{ Reagents } & $\mathrm{B} 10 . \mathrm{T}(6 \mathrm{R})$ & $\mathrm{AQR}$ & $\mathrm{B} 10 . \mathrm{M}$ \\
\cline { 3 - 4 } Serum absorbed on lymphocytes & $\mathrm{b}$ & $\mathrm{f}$ & $\mathrm{j}$ \\
Eluate from lymphocytes & $\mathrm{c}$ & $\mathrm{g}$ & $\mathrm{k}$ \\
Serum absorbed on platelets & $\mathrm{d}$ & $\mathrm{h}$ & $\mathrm{l}$ \\
Eluate from platelets & $\mathrm{e}$ & $\mathrm{i}$ & $\mathrm{m}$
\end{tabular}

The immunization combination being $(m \times b)$ anti-q $=\frac{k k k k k d}{\bar{b} b \overline{b b b}}$ anti-qqqqq, the use of the three indicated targets made it possible to dissociate the reactivity of the two antibodies, anti-H-2.17 and anti-Ia.13. The haplotype compositions for the target strains and for the immunization combination are listed in the order $K, I-A, I-B, I-C . S, D$. 
Table 2

Reactivity of serum \# $7(q \times d)$ anti-k before and after absorption on B10.K platelets, and of serum \# $21(q \times d)$ anti-yl against a panel of target strains

\begin{tabular}{|c|c|c|c|c|c|c|c|c|}
\hline \multirow{3}{*}{$\begin{array}{l}\text { Target } \\
\text { strains }\end{array}$} & & \multirow{3}{*}{$\begin{array}{l}\text { Haplo- } \\
\text { types }^{b}\end{array}$} & \multicolumn{5}{|c|}{ Immune ser $\mathrm{a}^{\mathrm{a}}$} & \multirow{3}{*}{$\begin{array}{c}\text { Relevant } \\
\text { specificities }^{d}\end{array}$} \\
\hline & & & \multicolumn{3}{|c|}{$\begin{array}{c}7 \\
\text { Unabsorbed }\end{array}$} & \multirow{2}{*}{$\begin{array}{c}7 \\
\text { Absorbed on } \\
\text { B10.K platelets }\end{array}$} & \multirow{2}{*}{$\frac{\begin{array}{c}21 \\
\text { Un- } \\
\text { absorbed }\end{array}}{\text { LCT }}$} & \\
\hline & & & $\mathrm{LCT}^{\mathrm{c}}$ & LyCF & $\mathrm{P} 1 \mathrm{CF}$ & & & \\
\hline \multicolumn{9}{|c|}{ Independent haplotypes } \\
\hline $\mathrm{B} 10 / \mathrm{Sn}$ & $b$ & & - & - & - & - & - & \\
\hline B10.D2 & d & & - & - & - & - & - & \\
\hline B10.M & $\mathrm{f}$ & & $640(70)$ & 80 & - & $320(63)$ & $320(73)$ & $?+\mathrm{Ia} .1 ?$ \\
\hline B10.WB & $\mathrm{j}$ & & $320(68)$ & 80 & - & $80(58)$ & $160(66)$ & $?$ \\
\hline B $10 . \mathrm{K}$ & $\mathrm{k}$ & & $1280(100)$ & 320 & 40 & $1280(78)$ & $1280(74)$ & $(\mathrm{H}-2.23) \mathrm{Ia} .2+\mathrm{Ia} .1 ?$ \\
\hline B10.P & $\mathrm{p}$ & & - & - & - & - & - & \\
\hline C3H.Q & $q$ & & - & - & - & - & - & \\
\hline B10.RIII & $\mathrm{r}$ & & $640(76)$ & 25 & - & $640(71)$ & $320(60)$ & $?$ \\
\hline B $10 . S$ & $\mathbf{s}$ & & $640(73)$ & 80 & - & $320(72)$ & $320(65)$ & $?$ \\
\hline \multicolumn{9}{|c|}{ Recombinant haplotypes } \\
\hline A.TL & $\mathrm{t} 1$ & skkkkd & $1280(75)$ & 50 & - & n.d. & $1280(75)$ & $\mathrm{Ia} .2+\mathrm{Ia} .1 ?$ \\
\hline AQR & yl & qkkddd & $640(77)$ & 80 & - & $640(67)$ & $2560(71)$ & $\mathrm{Ia} .2+\mathrm{Ia} .1 ?$ \\
\hline$B I 0 . A(4 R)$ & h4 & kkbbbb & $640(100)$ & 50 & 10 & n.d. & $1280(74)$ & $(\mathrm{H}-2.23) \mathrm{Ia} .2+\mathrm{Ia} .1 ?$ \\
\hline B $10 . A$ & $\mathrm{a}$ & kkkddd & $1280(100)$ & 100 & 10 & n.d. & $1280(83)$ & $(\mathrm{H}-2.23) \mathrm{la} .2+\mathrm{la} .1 ?$ \\
\hline $\mathrm{B} 10 . \mathrm{A}(5 \mathrm{R})$ & $i 5$ & bbbddd & $80(64)$ & - & - & n.d. & $40(41)$ & $?$ \\
\hline$B \perp 0 . S(9 R)$ & $\mathrm{t} 4$ & sssddd & $640(69)$ & 25 & - & $320(61)$ & $640(77)$ & $?$ \\
\hline $\mathrm{B} 10 . \mathrm{A}(3 \mathrm{R})$ & i3 & bbbddd & $80(72)$ & n.d. & n.d. & n.d. & $40(48)$ & $?$ \\
\hline $\mathrm{B} 10 . \mathrm{T}(6 \mathrm{R})$ & $y^{2}$ & qqqqqd & - & n.d. & n.d. & n.d. & - & \\
\hline BIO.HTT & $\mathrm{t} 3$ & ssskkd & $640(78)$ & n.d. & n.d. & n.d. & $320(74)$ & $?$ \\
\hline HTI & $\mathrm{i}$ & bbbbbd & - & n.d. & n.d. & n.d. & - & \\
\hline
\end{tabular}

\#7 (C3H.Q $\times$ B10.D2) anti-C3H = anti-H-2.23 + Ia1(?), Ia.2 - ?; \#21 (C3H.Q $\times$ B10.D2) anti-AQR = anti-Ia.1(?), Ia.2 - ?; \#7 absorbed, $250 \mu$ Ldiluted $1: 10$ were absorbed on $8 \times 10^{9} \mathrm{~B} 10 . \mathrm{K}$ platelets.

For recombinant haplotypes, the haplotype composition is indicated for the six regions or subregions of the $\mathrm{H}-2$ complex in the order: $K, I-A, I-B, I-C, S, D$.

LCT-Dye exclusion lymphocytotoxicity, LyCF-spleen lymphocyte complement fixation, P1CF-platelets complement fixation. Numbers indicate reciprocals of titers. Numbers in brackets indicate highest percentage of killing in LCT. - indicates negative at 1:10 dilution. n.d. indicates not done.

$\mathrm{H}-2.23$ is relevant only to the reactivity of serum \#7 unabsorbed.

Ia antibodies $(d, f, h, k)$ reacted only with $(6 R)$ and B 10.M lymphocytes. Reagents supposed to contain both anti-H-2 and anti-Ia antibodies (a, c, l) reacted with $(6 R)$ and $A Q R$ lymphocytes and platelets and with B 10.M lymphocytes. Reagents b and m supposed to contain no antibodies were nonreactive.
Absorption-elution analysis of a complex serum no. 7 ( $q \times \mathrm{d}$ ) anti-k: Out of the 20 sera studied this particular serum showed a number of extra reactions against the panel (Table 2). The expected antibodies in this immune serum were anti-H-2.23 and anti-Ia.1, 2. Apart from the expected reactions against the strains carrying the $H-2$ haplotypes $k, t l$, 
yl, h4, a, f, unexpected reactions were observed against the strains carrying the $H-2$ haplotypes $j, r, s, t 3, t 4, i 3, i 5$. All these latter reactions followed the Ia pattern and were not altered by absorption with $\mathrm{B} 10 . \mathrm{K}$ platelets. In addition, serum no. $21(q \mathbf{x} d)$ anti-yl which could contain only anti-Ia antibodies, reacted identically with serum no. 7 absorbed on B $10 . \mathrm{K}$ platelets or with the unabsorbed serum (except for an la pattern of reaction instead of the $\mathrm{H}-2$ pattern against $\mathrm{B} 10 . \mathrm{K}, \mathrm{B} 10 . \mathrm{A}$ and $\mathrm{B} 10 . \mathrm{A}(4 \mathrm{R})$ ).

An absorption-elution experiment using the lymphocytes of the strongly reacting strains was carried out in order to analyse these Ia reactions (Table 3 ). In every case the absorption was adequate since it removed all reactivity against the absorbing cells. B10.K lymphocytes carrying the immunizing haplotype cleared all reactivity. On the other hand, all the other cells tested failed to absorb the anti-H-2.23 antibody reacting with $\mathrm{B} 10 . \mathrm{K}$ lymphocytes and in addition left unabsorbed one or more antiIa antibodies (including anti-Ia.2) reacting with AQR lymphocytes. The absorption by B 10.S lymphocytes of the reactivity against B 10.M target cells (Ia.1(+)) suggested that serum no. 7 did not contain the expected anti-Ia.l antibody since B10.S is Ia. I(-). In addition, B 10.S cannot possess any Ia antigen cross-reacting with Ia.1 since the original anti-Ia.1 antibody was made in a recipient strain carrying the same $s$ genes as B 10.S at the $I$ region (David et al. 1973).

The results of absorption could be explained by three specificities $X, Y$ and $Z$, distributed as indicated in Table 3 (in addition to Ia.2). B 10.M and BI0.S behaved identically (cross-absorption); this showed that both strains carry the same specificities ( $\mathrm{X}$ and $\mathrm{Y}$ ). Specificity $\mathrm{X}$ is present on all the cells used for absorption; and is the only one carried by $\mathrm{B} 10 . \mathrm{WB}$ since all cells cleared the reactivity against $\mathrm{B} 10 . \mathrm{WB}$ lymphocytes. On the other hand, as absorption on Bl0.WB lymphocytes left some reactivity against the other cells, other specificities were involved. At least two distinct specificities ( $\mathrm{Y}$ and $\mathrm{Z}$ ) were needed since there was no crossabsorption between Bl0.RIII (Z) on the one hand and B10.M or B10.S (Y) on the other. All eluates were reactive against all targets in agreement with the hypothesis of one specificity (X) shared in common by all strains used for absorption.

An unexpected result was the reactivity remaining against $\mathrm{B} 10 . \mathrm{S}(9 \mathrm{R})$ lymphocytes after absorption on B10.S and B10.M lymphocytes. It was finally removed by a higher number of Bl0.S lymphocytes. But even then B10.M lymphocytes were ineffective. These results could be compared to the weak reactivity of sera nos. 7 and 21 against B 10.A(3R) and B 10.A(5R) (Table 2) and will be discussed later.

\section{Discussion}

The presence of $\mathrm{H}-2$ antigens on blood platelets has already been reported (Schanzer et al. 1974) and their H-2 antigenic content evaluated (1 lymphocyte $\sim 30$ platelets) (Colombani et al. 1975). The present evaluation (1 lymphocyte $\sim 100$ platelets) was somewhat lower. Such variations are likely to be due to experimental conditions, to the properties and perhaps the specificity of the antibody used for quantitative absorption. The best average estimate could then be 1 lymphocyte $\sim 50$ platelets. Ia antigens were not detectable on platelets, and their maximum amount estimated was less than $1: 35$ relative to the $\mathrm{H}-2$ antigenic content, which probably reflects a complete absence of Ia antigens. These results are in agreement with the ubiquitous distribution of $\mathrm{H}-2$ antigens, and the restricted distribution of Ia antigens.

The description of Ia antigens depends on the production of appropriate antisera. Specific anti-Ia antibodies can be induced in donor-recipient combinations where 
immunization against $H-2 K$ and $H-2 D$ products is blocked, as was the case for serum no. 21 . That is possible only when strains carrying the appropriate recombinant haplotypes are available. Another approach is to absorb the anti-H-2 antibodies from immune sera directed against the products of the whole $\mathrm{H}-2$ complex. Erythrocytes (Davies \& Hess 1974) and T cell tumours (Sachs \& Cone 1975) have already been used for that purpose. The present results show that blood platelets are very effective for such absorptions because of their relatively high $\mathrm{H}-2$ antigenic content in a small volume. They can be obtained from any strain. Another advantage is the stability of $\mathrm{H}-2$ antigens on platelets (more than one month at $+4^{\circ} \mathrm{C}$ ). The efficiency of the absorption was shown by the complete separation of anti-H-2.17 from anti-Ia.13 in a complex serum. This experiment was especially significant because in this particular serum the anti-H-2 antibody titre was much higher (1:2560) than the anti-Ia antibody titre (1:160). Such an absorption was even easier in the reverse situation, for example in

Table 3

Reactivity in the dye exclusion lymphocytotoxicity test serum of \# $7(q \times d)$ anti-k before and after absorption on lymphocyles, and of eluates from lymphocyles sensitized with serum \# 7

\begin{tabular}{|c|c|c|c|c|c|c|c|}
\hline \multirow{2}{*}{$\begin{array}{l}\text { Immune sera } \\
\text { and eluates }\end{array}$} & \multicolumn{7}{|c|}{ Target strains ${ }^{a}$} \\
\hline & $\begin{array}{l}\mathrm{BIO} \cdot \mathrm{K} \\
\mathrm{k}\end{array}$ & $\mid \begin{array}{c}\mathrm{AQR} \\
\text { yl-qkkddd }\end{array}$ & $\begin{array}{c}\text { B10.M } \\
\mathrm{f}\end{array}$ & $\begin{array}{c}\mathrm{B} 10 . \mathrm{S} \\
\mathrm{s}\end{array}$ & $\begin{array}{c}\text { B 10.RIII } \\
\mathbf{r}\end{array}$ & $\begin{array}{c}\text { B10.WB } \\
\text { j }\end{array}$ & $\begin{array}{c}\text { B } 10 . S(9 R) \\
\text { t4-sssddd }\end{array}$ \\
\hline $\begin{array}{l}\text { \#7 Unabsorbed } \\
\# 7 \text { Absorbed }^{c} \text { on lym }\end{array}$ & $\begin{array}{l}1280(100)^{\mathrm{b}} \\
\text { phocytes fror }\end{array}$ & $640(77)$ & $640(70)$ & $640(73)$ & $640(76)$ & $320(68)$ & $640(69)$ \\
\hline $\begin{array}{l}\text { B } 10 . \mathrm{K} \\
\text { AQR } \\
\text { B } 10 . \mathrm{M} \\
\text { B } 10 . S \\
\text { B 10.RIII } \\
\text { B10.WB }\end{array}$ & $\begin{array}{c}- \\
320(100) \\
640(100) \\
640(100) \\
640(100) \\
640(100)\end{array}$ & $\begin{array}{c}- \\
- \\
160(75) \\
320(77) \\
320(83) \\
640(80)\end{array}$ & $\begin{array}{c}- \\
- \\
- \\
- \\
20(41) \\
20(35)\end{array}$ & $\begin{array}{c}- \\
- \\
- \\
- \\
40(64) \\
20(60)\end{array}$ & $\begin{array}{c}- \\
\text { n.d. } \\
80(82) \\
80(78) \\
- \\
40(73)\end{array}$ & $\begin{array}{l}- \\
\text { n.d. } \\
- \\
- \\
- \\
-\end{array}$ & $\begin{array}{l}{ }^{-} \\
\text {n.d. } \\
40(46)^{d} / 20(30)^{e} \\
20(42)^{d} \\
30(70) \\
20(61)\end{array}$ \\
\hline $\begin{array}{l}\text { Eluates from sensitize } \\
\text { B } 10 . \mathrm{K} \\
\text { AQR } \\
\text { B } 10 . \mathrm{M} \\
\text { B } 10 . S \\
\text { B 10.RIII } \\
\text { B } 10 . \mathrm{WB}\end{array}$ & $\begin{array}{c}d \text { lymphocyt } \\
640(100) \\
80(70) \\
80(65) \\
80(67) \\
320(85) \\
160(70)\end{array}$ & $\begin{array}{r}\text { tes from } \\
320(68) \\
80(71) \\
80(59) \\
80(69) \\
320(79) \\
160(66)\end{array}$ & $\begin{array}{r}80(43) \\
20(40) \\
160(56) \\
40(49) \\
80(55) \\
80(48)\end{array}$ & $\begin{array}{r}160(65 \\
80(46 \\
160(61) \\
80(50) \\
160(65) \\
160(50)\end{array}$ & $\begin{array}{c}160(77) \\
\text { n.d. } \\
80(54) \\
40(60) \\
320(71) \\
160(50)\end{array}$ & $\begin{array}{l}40(45) \\
\text { n.d. } \\
40(50) \\
40(37) \\
80(46) \\
80(57)\end{array}$ & $\begin{array}{l}80(64) \\
\text { n.d. } \\
80(53) \\
40(60) \\
160(71) \\
160(52)\end{array}$ \\
\hline Relevant specificities & $\begin{array}{c}\text { XYZ } \\
\text { Ia.2 } \\
\text { H-2.23 }\end{array}$ & $\begin{array}{l}\mathrm{XYZ} \\
\mathrm{la} .2\end{array}$ & $\mathrm{XY}$ & $X Y$ & $X Z$ & $\mathrm{X}$ & $X Y-?$ \\
\hline
\end{tabular}

a For each strain the $\mathrm{H}-2$ haplotype is indicated. The haplotype compositions for the recombinant haplotypes are given in the order: $K, I-A, I-B, I-C, S, D$.

b Numbers indicate reciprocals of titers. Numbers in brackets indicate highest percentage of killing. indicates negative at $1: 10$ dilution, n.d. indicates not done.

- $250 \mu \mathcal{L}$ of serum diluted 1:10 were absorbed on $1 \times 10^{8}$ lymphocyres.

"Reactivity after the standard absorption.

e Reactivity after absorption using three times more lymphocytes.

f For acid elution $1 \times 10^{8}$ lymphocytes were sensitized with $100 \mu \mathcal{L}$ of undiluted serum. After washing, the elution was made in a volume of $50 \mu \mathcal{L}$. All sera and eluates were tested against C3H.Q lymphocytes with negative results. 
serum no. 7 in which the anti-H-2 antibody titre was 1:320 (after absorption on AQR lymphocytes, Table 3) while the anti-Ia titre was 1:640-1:1280 (after absorption on B10.K platelets, Table 2). These experiments showed also that anti-H-2 and anti-Ia antibodies could be easily eluted from their antigens at low $\mathrm{pH}$.

As shown by the study of 20 immune sera essentially developed against the products of the whole $\mathrm{H}-2$ complex, the association of anti-Ia to anti-H-2 antibodies is very frequent. More than half of the sera contained both kinds of antibodies. This observation together with the possibility of selective absorption of anti-H-2 antibodies on platelets from the immunizing strain, suggests that this approach will be useful for the description of new Ia specificities, particularly for the study of Ia antigens determined by haplotypes for which no recombinants are presently available.

It is already apparent that a large number of distinct Ia specificities are determined at the three (or more) loci of the $I$ region $-I-A, I-B, I-C$ (Shreffler \& David 1975 , Sachs et al. 1975). Analyses of two anti-H-2 ${ }^{k}$ sera (nos. 7 and 21) made possible the description of three new Ia specificities. They are distinct from the specificities already described as determined by the $H-2^{k}$ haplotype (Ia.1, 2, 3, 7) on the basis of their strain distributions, and because, of these specificities, serum no. 7 could contain antibody only to Ia.2, since immunization against Ia. 3 and 7 was blocked by the recipient combination. Absence of anti-Ia. I was shown by absorption analysis. These new la specificities are indeed determined at the $I$ region and most likely by the $I-A$ and/or $I-B$ subregion as shown by the reactivity of serum no. 7 against AQR lymphocytes and of serum no. 21 against the panel. In both cases the antibodies could be directed only against the products of $k$ genes at the $I-A$ and/or $I-B$ loci; in addition, the identical reactivities of the two sera suggested that they contained the same anti-Ia antibodies. Finally, the fact that $\mathrm{B} 10 . \mathrm{K}$ platelets failed to absorb these antibodies confirmed that the antigens recognized are not $\mathrm{H}-2 \mathrm{~K}$ or $\mathrm{H}-2 \mathrm{D}$ products.

The results of absorption with the reactive lymphocytes (Table 3) showed that three different specificities were involved, $X$ (which we propose to call Ia.17) determined by $H-2$ haplotypes $k, f, s, r, j, Y$ (Ia.18) determined by haplotypes $k, f, s, \mathrm{Z}$ (Ia.19 determined by haplotypes $k$ and $r$.

A recent study (Götze 1975) of a serum $(\mathrm{DBA} / 1 \times \mathrm{B} 10 . \mathrm{D} 2)$ anti-AQR $[(q \times d)$ anti-yl)] showed that it reacted with la antigens expressed on $B$ and $T$ cells from $H-2^{k}$ strains. Absorption studies indicated that $B$ cells possess at least two Ia antigens, one being shared with $T$ cells. This serum was essentially similar to serum no. 21 .

Even with these new specificities certain facts remained unexplained-the difficulty in absorbing out the reactivity of serum no. 7 against B 10.S(9R) lymphocytes with B $10 . S$ and $\mathrm{B} 10 . \mathrm{M}$ lymphocytes, and the weak reactivity of both no. 7 and no. 21 sera against B 10.A(3R) and B10.A(5R) lymphocytes. Some of these reactions might have been attributed to an anti-Tla.I, 3 antibody which could have been produced in both sera (Frelinger et al. 1974b)-( $q, T 1 a^{\mathrm{b}} \times d$, $\left.T l a^{c}\right)$ anti-k or anti-yl, both $T l a^{a}$; B 10.S(9R), B10.A(5R) are TIa $(\mathrm{B} 10 . \mathrm{A}(3 \mathrm{R})$ is also very likely $T 1 a^{a}$ ). However, both sera were non-reactive against $\mathrm{B} 10 . \mathrm{A}(6 \mathrm{R})$ which is also $T l a^{\mathrm{a}}$ (Table 2), and Bl0.M(Tla $a^{\mathrm{a}}$ ) lymphocytes did not absorb all reactivity against B $10 . S(9 R)$. The possibility of these weak reactions being due to an anti-T la. 1, 3 antibody was thus ruled out. Another possibility was that the recombinant haplotypes $(t 4, i 3, i 5)$ carried a chromosomal segment of $k$ origin located between the I-B and I-C subregions. This hypothesis is compatible with the origin of these recombinants from 
the $\mathrm{H}-2^{\mathrm{a}}$ haplotype (haplotype composition $k k k d d d)$ which should then carry the same $k$ segment. Moreover, this segment should also be present in the $H-2^{2^{1}}$ haplotype of $A Q R$, whose lymphocytes were used for immunization in the production by B10.S and $B 10 . M$ of the reactivity against B 10.S(9R). The complete absorption obtained by increasing the amount of B10.S lymphocytes would have to be due to nonspecific absorption of a weak antibody. This hypothesis would also explain the reactivity of both immune sera against B10.A(3R) and B 10.A(5R) lymphocytes (bbbddd) even though B10/Sn (bbbbb) and B10.D2 (ddddd) are non-reactive as they are due to the same $k$ segment derived from $H-2^{2}$. Experiments are in progress to test this hypothesis (Sachs et al. 1975, David \& Shreffler, in preparation).

\section{Acknowledgements}

The authors are greatly indebted to John McCormick, Ronald Jackson and John Wilson for excellent technical help and Mrs. Mary Kellogg for expert secretarial assistance.

\section{References}

Benacerraf, B. \& McDevitt, H. O. (1972) Histocompatibility linked immune response genes. Science 173, 273-279.

Colombani, J., Colombani, M., Shreffler, D. C. \& David, C. S. (1975) A lymphocyte and platelet complement fixation microtechnique for the study of $\mathrm{H}-2$ region and $\mathrm{I}$ region associated (la) antigens. Transplaniation 20, 84-88.

David, C. S., Shreffler, D. C. \& Frelinger, J. A. (1973) New lymphocyte antigen system (Lna) controlled by the $\mathrm{I} r$ region of the mouse $\mathrm{H}-2$ complex. Proc. nat. Acad. Sci. (Wash.) 70, 2509-2514.

Davies, D. A. L. \& Hess, M. (1974) New alloantigen genetically linked to the major histocompatibility locus of the mouse. Nature (Lond.) 250, 228-230.

Démant, P. (1973) H-2 gene complex and its role in alloimmune reactions. Transplant. Rev. 15, 162-200.
Frelinger, J. A., Niederhuber, J. E., David, C. S. \& Shreffler, D. C. (1974a) Evidence for the expression of Ia (H-2 associated) antigens on thymus derived lymphocytes. J. exp. Med. 140, 1273-1284.

Frelinger, J. A., Murphy, D. B. \& McCormick, J. F. (1974b) Tla type of $\mathrm{H}-2$ congenic and recombinant mice. Transplantation 18, 292-294.

Götze, D. (1975) T(lat)- and B(Iab)-cell alloantigens determined by the $H-2$ linked $I$ region in mice. Immunogenetics 1, 495-505.

Hammerling, G. J., Deak, B. D., Mauve, G., Hammerling, U. \& McDevitt, H. O. (1974) B lymphocyte alloantigens controlled by the $I$ region of the major histocompatibility complex in mice. Immunogenetics 1, 68-81.

Hauptfeld, V., Klein, D. \& Klein, J. (1973) Serological identification of an Ir region product. Science 181, 167-169.

Hauptfeld, V., Hauptfeld, M. \& Klein, J. (1974) Tissue distribution of $I$ region associated antigens in the mouse. J. Immunol. 113, 181-188.

Klein, J, Démant, P., Festenstein, H., McDevitt, H. O., Shreffler, D. C., Snell, G. D. \& Stimpfling, J. H. (1974) Genetic nomenclature for the $\mathrm{H}-2$ complex of the mouse. Immunogenetics 1, 184-188.

McDevitt, H. O., Bechtol, K. B., Hammerling, G. J., Lonai, P. \& Delovitch, T. L. (1974) Ir genes and antigen recognition. The Immune System, Genes, Receptors, Signals, ed. Sercarz, E. E., Williamson, A. R. \& Fox, C. F., p. 597-632. Academic Press, New York.

Sachs, D. H. \& Cone, J. L. (1973) A mouse B cell alloantigen determined by gene(s) linked to the major histocompatibility complex. J. exp. Med. 138, 1289-1304.

Sachs, D. H., David, C. S., Shreffler, D. C., Klein, J., Nathenson, S. G. \& McDevitt, H. O. (1975) Ir associated antigens. Summary of the Proceedings of a Workshop on Ia antigens (Nov. 1974). Immunogenetics 2, 301-312.

Sachs, D. H. \& Cone, J. L. (1975) Ir-associated murine alloantigens: demonstration of multiple Ia specificities in $\mathrm{H}-2$ alloantisera following selective absorption. $J$. Immunol. 114, 165-170.

Schanzer, H., Severin, C. \& Taub, T. N. (1974) Platelet cyclophosphamide induced immunological tolerance to skin graft in mice. Transplantation 17, 431-435.

Shreffler, D. C., Amos, D. B. \& Mark, R. (1966) Serological analysis of a recombination in the $\mathrm{H}-2$ region of the mouse. Transplantation 4, $300-322$. 
Shreffler, D. C., David, C. S., Götze, D., Klein, J., McDevitt, H. O. \& Sachs, D. (1974) Genetic nomenclature for new lymphocyte antigens controlled by the Ir region of the $\mathrm{H}-2 \mathrm{com}$ plex. Immunogenetics 1, 189-190.

Shreffler, D. C. \& David, C. S. (1975) The H-2 major histocompatibility complex and the $I$ immune response region: Genetic variation, function and organisation. Adv. Immunol. $\mathbf{2 0}$, 125-195.

Shulman, N. R., Marder, V. J., Hiller, M. C. \& Collier, E. M. (1964) Platelet and leukocyte isoantigen and their antibodies. Serologic, physiologic and clinical studies. Prog. Hematol. 4, 222-304.

Snell, G. D. \& Stimpfling, J. H. (1964) Genetics of tissue transplantation. Biology of the Laboratory Mouse, ed. Green, E. L., p. 486-491. McGrawHill, New York.
Thorsby, E. \& Bratlie, A. (1970) A rapid method for preparation of pure lymphocyte suspensions. Histocompatibility Testing 1970, p. 655-656. Munksgaard, Copenhagen.

Unanue, E. R., Dorf, M. E., David, C. S. \& Benacerraf, B. (1974) The presence of $I$ region associated antigens on $B$ cells in molecules distinct from immunoglobulin and H-2K and H-2D. Proc. nat. Acad. Sci. (Wash.) 71, 5014-5016.

Address:

J. Colombani

Unité de Recherche sur l'Inmunogénétique de l'Histocompatibilité Humaine

U93 INSERM

Hôpital Saint-Louis

75475 Paris Cedex 10

France 